\title{
Biochemical Evaluation and Green Synthesis of Nano Silver Using Peroxidase from Euphorbia (Euphorbia amygdaloides) and Its Antibacterial Activity
}

\author{
Semra Cicek, ${ }^{1,2}$ Azize Alaylı Gungor, ${ }^{3}$ Ahmet Adiguzel, ${ }^{4}$ and Hayrunnisa Nadaroglu ${ }^{1,5}$ \\ ${ }^{1}$ Department of Nanoscience and Nanoengineering, Faculty of Engineering, Ataturk University, 25240 Erzurum, Turkey \\ ${ }^{2}$ Department of Agricultural Biotechnology, Faculty of Agriculture, Ataturk University, 25240 Erzurum, Turkey \\ ${ }^{3}$ Department of Chemical Technology, Erzurum Vocational Training School, Ataturk University, 25240 Erzurum, Turkey \\ ${ }^{4}$ Department of Molecular Biology and Genetics, Faculty of Science, Ataturk University, 25240 Erzurum, Turkey \\ ${ }^{5}$ Department of Food Technology, Erzurum Vocational Training School, Ataturk University, 25240 Erzurum, Turkey
}

Correspondence should be addressed to Hayrunnisa Nadaroglu; hnisa25@atauni.edu.tr

Received 29 June 2015; Accepted 24 August 2015

Academic Editor: Mallikarjuna N. Nadagouda

Copyright (C) 2015 Semra Cicek et al. This is an open access article distributed under the Creative Commons Attribution License, which permits unrestricted use, distribution, and reproduction in any medium, provided the original work is properly cited.

\begin{abstract}
Silver nanoparticles are used an increased attention for various biomedical and medical applications. In this study, green synthesis of silver nanoparticles was made with simple method by using peroxidase enzyme partially purified from Euphorbia (Euphorbia amygdaloides) plant. Optimum $\mathrm{pH}$, temperature and time period were determined to obtain silver nanoparticles using the peroxidase enzyme. The result shows that higher silver nanoparticle was synthesized for 4 hours and at $20^{\circ} \mathrm{C}$ and $\mathrm{pH} 8$. Also, optimal concentration of metal ions was found as $0.5 \mathrm{mM}$. The synthesized silver nanoparticles were characterized by UV spectrum, scanning electron microscope (SEM) and X-ray diffraction. Antibacterial activity of silver nanoparticles was measured against some microorganisms such as Serratia marcescens, Yersinia pseudotuberculosis, Klebsiella pneumoniae, Staphylococcus aureus, Staphylococcus epidermidis, Streptococcus pyogenes, Pseudomonas aeruginosa, Salmonella typhimurium, Listeria monocytogenes, and Escherichia coli. Synthesized silver nanoparticles have wide spectrum antibacterial activity in low concentration and may be a good alternative therapeutic approach in medicine and pharmaceutical fields in future.
\end{abstract}

\section{Introduction}

Metal nanoparticles (gold, silver, platinum, etc.) have features such as crystal structures and very strong metallic bonds and they are commonly used in many fields such as industrial products, machinery industry, biomedical and medical areas, diagnosis, biomarkers, cell labeling, antimicrobial agents, drug administration, environmental pollution control, drug delivery systems, cancer therapy, biosensors, and material chemistry $[1,2]$. Silver nanoparticles (Ag-NPs) have potential for use in many fields such as, mainly, the medical field, food, cosmetics, materials science, medicine, environmental remediation, nonlinear optics, biolabeling, and optical receptor because of their features such as good electrical activity, chemical stability, and catalytic and antibacterial activity [3, 4].
Physical and chemical methods such as UV radiation, microwave radiation [5], chemical reducing [6], photochemical method [7], and heat evaporation are available in the production of nanoparticles. However, these methods include the use of toxic chemical which can cause serious problems in terms of human, animal, and environment as opposed to a growing environmental awareness. And more than one reaction step increases high cost depending on high energy requirements. In addition, difficulties in the purification step lead to obtaining low yields of nanoparticles.

Due to this reason, economic and environmentally friendly methods have been developed to contribute to green chemistry. For this purpose, using of plant extracts and biological microorganisms (bacteria, fungi, and yeast) in order to perform enzymatical synthesis of nanoparticles has come into prominence $[8,9]$. 
Some studies have been made for the production of nanoparticles by using plant extracts: Achillea biebersteinii [10], Cassia auriculata [11], Acacia farnesiana [12], Gloriosa superba [13], Alternanthera dentata [14], Cocos nucifera [15], and so forth. However very few studies were found for synthesis of nanoparticles by using peroxidase enzyme.

Peroxidase (EC 1.11.1.7; donor: hydrogen-peroxide oxidoreductase) is an oxidoreductase that catalyzes the reaction between the compounds which tend to give its hydrogen atoms with $\mathrm{H}_{2} \mathrm{O}_{2}$ receiving these atoms. Peroxidases have wide usage area in clinical biochemistry, immunoassays, food processing, detergent formulations, wastewater treatment, and synthesis of aromatic compounds [16].

In this research, peroxidase (POX) enzyme was partially purified by ammonium sulfate precipitation from plant of Euphorbia (Euphorbia amygdaloides) and silver nanoparticles were synthesized using the purified peroxidase. At the same time, the obtained nanoparticles were characterized by UV spectrum, scanning electron microscope (SEM), and X-ray diffraction. The antibacterial activity of newly synthesized nano silver NPs was assayed.

\section{Experimental}

2.1. Collection of Plant Sample and Preparation of Plants Extract. Used Euphorbia (Euphorbia amygdaloides) in the study was collected from near the town of Hasankale of Erzurum, Turkey, and it was identified with the helping of taxonomists. Plants were washed with distilled water several times for cleaning dust and soil on plants. Then, plants were cut into small pieces. Small pieces $(50 \mathrm{~g})$ were thoroughly shattered to form a homogeneous mixture in blander using $250 \mathrm{~mL}, 10 \mathrm{mM}$ sodium phosphate buffer (pH: 6). Then, it was centrifuged at $5000 \times \mathrm{g}$ for $10 \mathrm{~min}$ and the supernatant was used for enzyme purification [17].

2.2. Partial Purification of the Peroxidase Enzyme with Ammonium Sulphate Precipitation. Prepared Euphorbia (Euphorbia amygdaloides) plant homogenate was saturated from 60 to $80 \%$ with ammonium sulphate; then the peroxidase enzyme was precipitated by centrifuging at $8000 \times \mathrm{g}, 10 \mathrm{~min}$. Obtained precipitate was dissolved at $10 \mathrm{mM}$ sodium phosphate buffer ( $\mathrm{pH}:$ 6.0) and was incubated at $4^{\circ} \mathrm{C}$ for further analysis [17].

2.3. Peroxidase Enzyme Activity Test. Determination of peroxidase activity was made by substrate of $1 \mathrm{mM} 2,2^{\prime}$-azinobis(3-ethylbenzthiazoline-sulfonic acid) diammonium salt (ABST) prepared in $0.1 \mathrm{M}$ phosphate buffer at $\mathrm{pH}$ 6. For this purpose, $2.8 \mathrm{~mL}$ ABST was transferred to a test tube; then the reaction mixture was formed by the addition $100 \mu \mathrm{L}$ of $80 \%$ enzyme and $100 \mu \mathrm{L}$ of $3.2 \mathrm{mM} \mathrm{H}_{2} \mathrm{O}_{2}$ solution into the test tube. The change in absorbance was monitored at $412 \mathrm{~nm}$ using UV-visible spectrophotometer at $1 \mathrm{~min}$ intervals for $3 \mathrm{~min}$. Blank test tube was prepared using distilled water instead of enzyme in the reaction mixture.

2.4. Synthesis of Silver Nanoparticles. $100 \mu \mathrm{L}$ of purified peroxidase enzyme from Euphorbia (Euphorbia amygdaloides) plant was added in sample of silver nitrate solution $\left(\mathrm{AgNO}_{3}\right)$ $(2.9 \mathrm{~mL}, 10 \mathrm{mM})$ and incubated in a closed space for 4 hours. The solution was becoming dark brown, which indicates the presence of Ag nanoparticles. Then, water was removed by helping of evaporatory and synthesized silver nanoparticles that were dried at $70^{\circ} \mathrm{C}$ for 24 hours $[18,19]$.

2.5. Characterization of Silver Nanoparticles. Synthesized silver nanoparticles were characterized with scanning at range of 200-1000 nm by using UV-VIS spectrophotometer (PG Instrument T80 UV-VIS spectrophotometer). Determination of topography silver nanoparticles was performed by SEM (scanning electron microscope). In addition, XRD analysis (X-ray diffraction analysis) was performed to determine the size of Ag nanoparticles.

2.6. Biochemical Properties of Silver Nanoparticles Synthesis. Contact time, $\mathrm{pH}$, temperature, and metal ion concentration were determined for the purpose of optimization synthesized Ag nanoparticles.

2.6.1. The Optimum Contact Time. For determination of the optimum contact time, samples were spectrophotometrically measured between 0 and 240 min with 3 min intervals.

2.6.2. The Determination of Optimum $p H$. Synthesis of silver nanoparticles was performed in sodium phosphate buffer at pH 2-3, sodium acetate buffer at $\mathrm{pH} 4-6$, sodium phosphate buffer at $\mathrm{pH} 7,8$, and sodium carbonate buffer at $\mathrm{pH}$ 9-11 and the values of absorbance were measured by UV-visible spectrophotometer. $\mathrm{pH}$ was adjusted by using $0.1 \mathrm{~N} \mathrm{HCI}$ and $0.1 \mathrm{~N} \mathrm{NaOH}$.

2.6.3. The Determination of Optimum Temperature. Synthesis of nanoparticles was separately carried out from $10^{\circ} \mathrm{C}$ to $90^{\circ} \mathrm{C}$, respectively, and changes in absorbans of the samples were measured by UV-visible spectrophotometer.

2.6.4. The Determination of Optimum Concentration of Metal Ion. Synthesis of silver nanoparticles was performed by using silver nitrate solution at $0.5 \mathrm{mM}, 1 \mathrm{mM}, 3 \mathrm{mM}, 5 \mathrm{mM}$, and $7 \mathrm{mM}$ and the absorbance of samples was measured by UVvisible spectrophotometer.

2.7. Antibacterial Activity of Silver Nanoparticles against Bacteria in Petri Dish. Antagonistic activity of synthesized silver nanoparticles was determined against bacteria [20, 21]. Sterile nutrient agar (NA-Oxoid) was prepared and sterilized throughout one night. The discs $6 \mathrm{~mm}$ in diameter taken from the pathogenic bacteria culture growing on NA were placed in the center of petri dishes containing nutrient agar media. And bacterial cultures of $1 \times 10^{8}$ cells $/ \mathrm{mL}$ concentration were drawn around these pathogen-inoculated petri dishes. Each bacterium was studied in 3 replications, and the average inhibition zone created by bioagent was identified with the help of the values obtained. 
TABLE 1: The purification process of purified peroxidase enzyme from Euphorbia (Euphorbia amygdaloides).

\begin{tabular}{|c|c|c|c|c|c|c|c|}
\hline \multirow{2}{*}{$\begin{array}{l}\text { Enzyme } \\
\text { fraction }\end{array}$} & \multirow{2}{*}{$\begin{array}{c}\text { Volume } \\
\mathrm{mL}\end{array}$} & \multirow{2}{*}{$\begin{array}{l}\text { Activity } \\
\mathrm{EU} / \mathrm{mL}\end{array}$} & \multicolumn{2}{|c|}{ Total activity } & \multirow{2}{*}{$\begin{array}{l}\text { Protein } \\
(\mathrm{mg} / \mathrm{mL})\end{array}$} & \multirow{2}{*}{$\begin{array}{c}\text { Specific activity } \\
\mathrm{EU} / \mathrm{mg}\end{array}$} & \multirow{2}{*}{$\begin{array}{l}\text { Purification } \\
\text { fold }\end{array}$} \\
\hline & & & EU & $\%$ & & & \\
\hline Crude extract & 50 & $216.5 \pm 1.3$ & $10.83 \times 10^{3}$ & 100 & 33.3. \pm 0.2 & 0.272 & - \\
\hline $\begin{array}{l}\left(\mathrm{NH}_{4}\right)_{2} \mathrm{SO}_{4} \\
(40-80)\end{array}$ & 20 & $175.7 \pm 1.02$ & $3.51 \times 10^{3}$ & 32.4 & $3.88 \pm 0.38$ & 8.12 & 29.85 \\
\hline
\end{tabular}

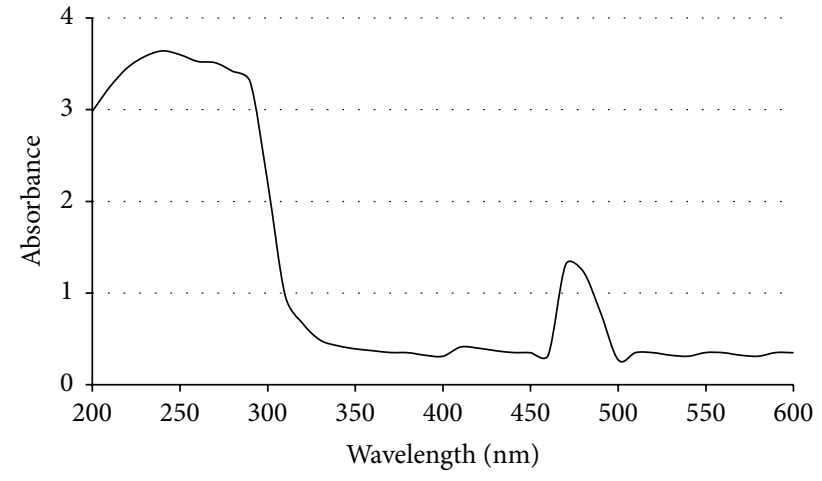

FIGURE 1: UV-vis spectra of silver nanoparticles.

\section{Results and Discussion}

Peroxidase enzyme was partially purified from Euphorbia (Euphorbia amygdaloides). For this purpose, the highest collapse of peroxidase enzyme was observed in the range of $60-80 \%$ ammonium sulphate saturation by performing ammonium sulphate precipitation in the range of $0-90 \%$ for Euphorbia (Euphorbia amygdaloides) plant homogenate. The enzyme was purified with a yield of $32.4 \%$ and 29.9 purification-fold from Euphorbia (Euphorbia amygdaloides) plant (Table 1).

$100 \mu \mathrm{L}$ purified peroxidase enzyme ( $5 \mathrm{mg}$ protein $/ \mathrm{mL}$ ) from Euphorbia (Euphorbia amygdaloides) plant was added to the $\mathrm{AgNO}_{3}$ sample $(2.9 \mathrm{~mL}, 1 \mathrm{mM})$. When it was stirred, color of the reaction mixture was changed from colorness to dark brown. This color change showed formation of silver nanoparticles.

3.1. Characterization of the Synthesized Silver Nanoparticles. The absorbance values of synthesized silver nanoparticles were measured against distilled water using UV-VIS spectrophotometer. UV-visible spectra of silver nanoparticles synthesized by reduction of the compound $\mathrm{AgNO}_{3}$ and also catalyzed with purified peroxidase enzyme from Euphorbia (Euphorbia amygdaloides) plant were showed in Figure 1 (at room temperature, for 4 hours). It was observed that the color of the reaction medium was changed from colorness to dark brown due to excitation of surface plasmon vibration of silver nanoparticles. The peaks of synthesized silver nanoparticles by peroxidase enzyme were in the range of 390 to $440 \mathrm{~nm}$ and the sharpest peak of these nanoparticles was observed at $412 \mathrm{~nm}$ (Figure 1). The sharp peak at $412 \mathrm{~nm}$ exhibited the characteristic peak of synthesized silver nanoparticles.

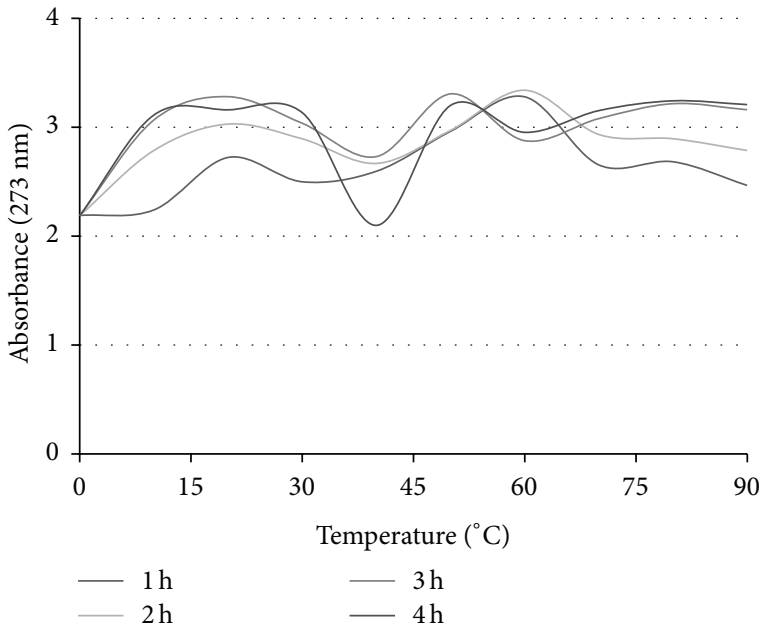

FIGURE 2: The effect of temperature on the synthesis of silver nanoparticles using peroxidase enzyme from Euphorbia (Euphorbia amygdaloides).

A number of studies belong to silver nanoparticles that were identified and their characteristic UV-VIS peaks were also around $400 \mathrm{~nm}$. For example, the peaks of silver nanoparticles were at wavelength of $390 \mathrm{~nm}$ and $420 \mathrm{~nm}$ in the synthesis of silver nanoparticle with redox reactions, for saccharose and maltose, respectively. Ag NPs synthesized by using olive leaf extracts showed characteristic peak in the range of $440-458 \mathrm{~nm}$ and they supported our experiments $[20,21]$.

3.1.1. Effect of Temperature. UV-visible spectra of silver nanoparticle prepared at different temperatures were given in Figure 2. It was observed that the temperature increases and the absorbance increases in Figure 2.

It has been observed that synthesis of silver nanoparticles was performed with high amounts at room temperature with catalyzed peroxidase enzyme purified from Euphorbia (Euphorbia amygdaloides). When the synthesis of Ag nanoparticle was done at room temperature, the great disadvantages could be prevented, spending extra energy and loss of its activity by denaturing of protein structure of peroxidase enzyme at high temperature.

3.1.2. Effect of $p H$. The effect of $\mathrm{pH}$ was investigated in the synthesis of Ag nanoparticles. UV-visible spectra of silver nanoparticles prepared at different $\mathrm{pH}$ were given in Figure 2. For this purpose, the synthesis of Ag nanoparticles was performed in the range of $\mathrm{pH} 3-11$. Different chemical reagents 


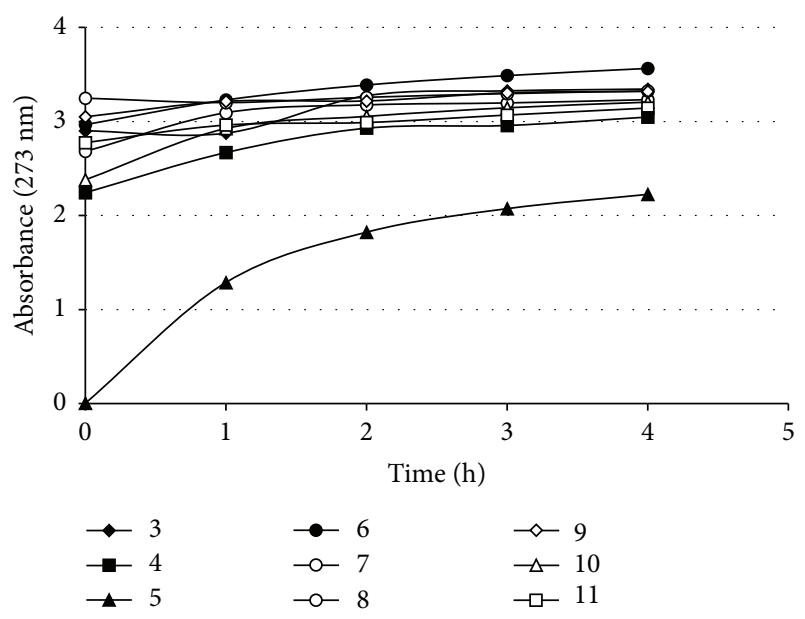

FIgURE 3: The effect of $\mathrm{pH}$ on the synthesis of silver nanoparticles using peroxidase enzyme from Euphorbia (Euphorbia amygdaloides).

were used for preparing appropriate buffer solutions ( $\mathrm{pH}$ 2-3 phosphate buffers, $\mathrm{pH}$ 4-5-6 acetate buffers, $\mathrm{pH}$ 7-8 phosphate buffers, and $\mathrm{pH}$ 9-10-11 carbonate buffers). It was shown in Figure 3 that the $\mathrm{pH}$ values were affected a little on synthesis of nanoparticle but the highest synthesis of Ag NPs occurred at $\mathrm{pH}$ 6. In a study, conducted by Güngör et al. [17], optimum $\mathrm{pH}$ of purified peroxidase enzyme from Euphorbia (Euphorbia Amygdaloides) plant was found as 6.0. Considering this situation, it was determined that synthesis of nanoparticle catalyzed by obtained peroxidase enzyme from Euphorbia (Euphorbia Amygdaloides) plant was performed at the highest rate at $\mathrm{pH} 6.0$ which was the optimum $\mathrm{pH}$ of the enzyme. The synthesis of Ag NPs was also performed at room temperature, $\mathrm{pH} 6.0$ (Figure 3). It was determined that the reaction rate was increased after 4 hours and $\mathrm{Ag}^{+}$almost completely reduced to $\mathrm{Ag}^{0}$.

In the synthesis of Ag NPs performed with olive leaf extracts, optimum $\mathrm{pH}$ was found to be $\mathrm{pH} 8$, the most stable $\mathrm{pH}$ of olive leaf extract as antioxidative [21, 22].

3.1.3. Effect of Contact Time at Room Temperature. The reduction reaction of $\mathrm{Ag}^{+}$by catalyzed peroxidase enzyme obtained from Euphorbia (Euphorbia amygdaloides) plants was observed for 4 hours. The graphic of absorbance changes depending on time of synthesis reaction of Ag NPs was given in Figure 4.

The absorbance values were monitored at $412 \mathrm{~nm}$ and show increase with time. The reactions of synthesis of Ag NPs were completed rate of $97 \%$ after 4 hours, followed during one day. From the obtained results, it was determined that Ag NPs were prepared using green synthesis method, they were not aggregate, and obtained nanoparticles were stable. Also, nanoparticles were stable and were not degrading during one week.

Some studies show longer stability than one week for syntheses of Ag NPs. These findings supported our research $[19,23]$.

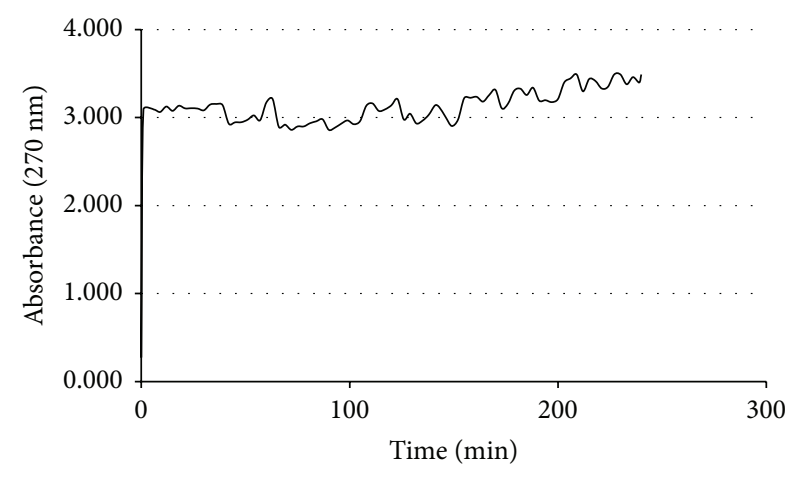

FIGURE 4: UV-visible spectra of Ag nanoparticles as function of time at room temperature and $\mathrm{pH} 6$.

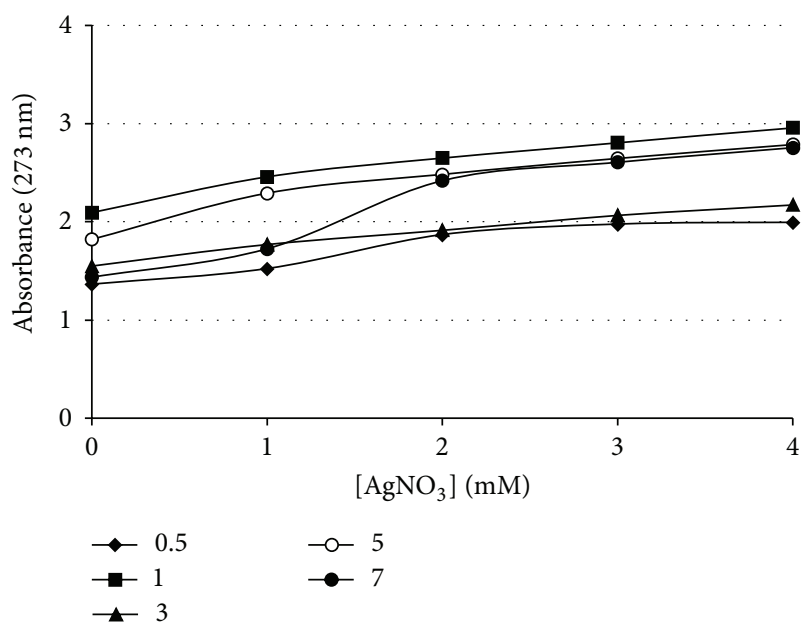

Figure 5: The effect of concentration of $\mathrm{AgNO}_{3}$ on the synthesis of silver nanoparticles using peroxidase enzyme from Euphorbia (Euphorbia amygdaloides).

3.1.4. Effect of $\mathrm{AgNO}_{3}$ Concentration. The effect of $\mathrm{AgNO}_{3}$ concentration was investigated on the synthesis of Ag NPs using peroxidase enzyme. For this purpose, Ag NPs were synthesized at different concentration $(0.5,1,3,5$ ve $7 \mathrm{mM})$ of $\mathrm{AgNO}_{3}$ using the same amount of enzyme.

The increasing concentration of $\mathrm{AgNO}_{3}$ increased synthesis of Ag NPs for 4 hours in Figure 5. However, the reaction synthesis of Ag NPs was performed at concentration of $1 \mathrm{mM}$ $\mathrm{AgNO}_{3}$ concentration; the stability of reaction was increased as more stable (Figure 5). In general, its concentration of $1 \mathrm{mM}$ seems appropriate for both measured and followed reaction. So, $1 \mathrm{mM}$ concentration of $\mathrm{AgNO}_{3}$ was used in all performed studies [17].

3.2. XRD Studies. XRD and crystallographic analysis of produced Ag NPs by catalyzed peroxidase enzyme were given in Figure 6.

The characteristic peaks of silver from XRD spectrum at $2 \theta=38^{\circ}, 43^{\circ}, 63^{\circ}, 82^{\circ}$ can be indexed at (111), (200), (220), and (311) facets which agree with the values reported for face centered cubic (fcc) silver nanocrystals [24]. 


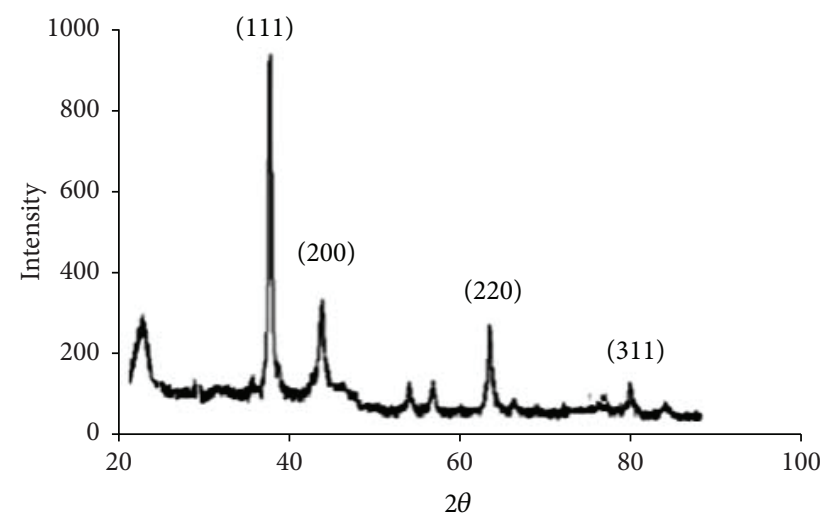

FIgURE 6: X-ray diffraction pattern of the synthesis of silver nanoparticles using peroxidase enzyme from Euphorbia (Euphorbia amygdaloides).

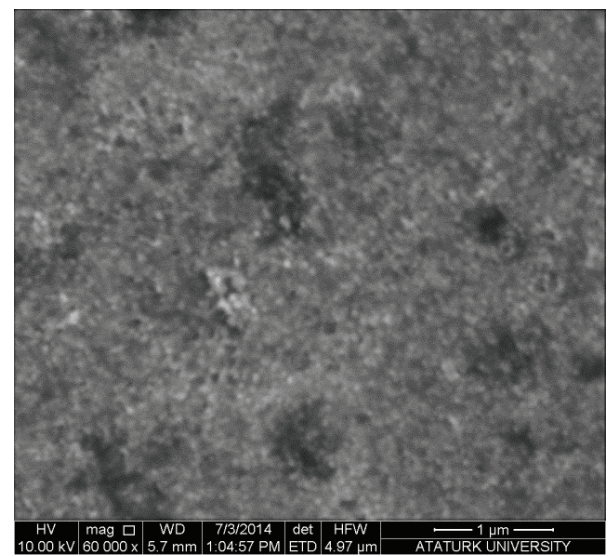

FIGURE 7: SEM image of the synthesized silver nanoparticles.

3.3. Surface Characterization of $A G$ NPs. Chemical and mineralogical compositions of green synthesized Ag NPs were determined by scanning electron microscopy. Scanning electron microscope (SEM) was used to examine the surface of adsorbent. Images of Ag NPs were magnified 5000 times by Metek, Apollo prime, active area $10 \mathrm{~mm}^{2}$, Microscope inspect S50, and SE detector R580 (Figure 7). It is observed from Figure 7 that most of the Ag nanoparticles were spherical in shape. Figure 7 shows well dispersed Ag NPs have identified in the sizes range of $7-20 \mathrm{~nm}$.

Many synthesized Ag NPs using plant extract mainly were determined as of spherical shape and $5-35 \mathrm{~nm}$ in size $[24,25]$.

3.4. Antibacterial Activity. Antibacterial effect of silver is known. Antibacterial activity of synthesized Ag NPs by catalyzed peroxidase enzyme from Euphorbia (Euphorbia amygdaloides) plant was studied using the disc diffusion method against Serratia marcescens, Yersinia pseudotuberculosis, Klebsiella pneumoniae, Staphylococcus aureus, Staphylococcus epidermidis, Streptococcus pyogenes, Pseudomonas aeruginosa, Salmonella typhimurium, Listeria monocytogenes, and Escherichia coli O157:H7.
TABLE 2: Diameter zone of inhibition by Ag NPs and $\mathrm{AgNO}_{3}$ against human pathogenic bacteria.

\begin{tabular}{|c|c|c|c|}
\hline \multirow{2}{*}{$\begin{array}{l}\text { Serial } \\
\text { number }\end{array}$} & \multirow{2}{*}{ Pathogenic bacteria } & \multicolumn{2}{|c|}{ Inhibition zone $(\mathrm{mm})$} \\
\hline & & Ag NPs & $\mathrm{AgNO}_{3}$ \\
\hline 1 & Serratia marcescens & 18.0 & 5 \\
\hline 2 & Yersinia pseudotuberculosis & 18.5 & 5 \\
\hline 3 & Klebsiella pneumoniae & 19.0 & 5 \\
\hline 4 & Staphylococcus aureus & 11.0 & 5 \\
\hline 5 & Staphylococcus epidermidis & 11.0 & 5 \\
\hline 6 & Streptococcus pyogenes & 17.0 & 5 \\
\hline 7 & Pseudomonas aeruginosa & 16.0 & 5 \\
\hline 8 & Salmonella typhimurium & 18.5 & 5 \\
\hline 9 & Listeria monocytogenes & 11.0 & 5 \\
\hline 10 & Escherichia coli $\mathrm{O} 157: \mathrm{H7}$ & 17.5 & 5 \\
\hline
\end{tabular}

The diameter of inhibition zones $(\mathrm{mm})$ around each well with silver nanoparticles solution is represented in Table 2. The silver nanoparticles synthesized by peroxidase enzyme from Euphorbia (Euphorbia amygdaloides) $(10 \mathrm{~mL})$ are found to have highest antimicrobial activity against Klebsiella pneumoniae $(19.0 \mathrm{~mm})$, Yersinia pseudotuberculosis $(18.5 \mathrm{~mm})$, and Salmonella typhimurium $(18.5 \mathrm{~mm})$. Then negative control (DMSO and distilled water) showed activity against all the microbial strains tested and no activity was observed against pathogens. The positive control $\left(\mathrm{AgNO}_{3}\right)$ showed activity against all the microbial strains tested and the activity against all bacteria was observed as $5.0 \mathrm{~mm}$.

Ag NPs gain the ability to easily pass through the cell membrane of bacteria with the increase in surface area due to the fact that size of Ag NPs is small. Thus, the antibacterial activity of Ag NPs increases. From obtained results, it was concluded that synthesized Ag NPs could easily pass into bacteria and have high interaction with its surface. Synthesized Ag NPs were quite effective on microorganisms. Findings of some studies supported our work. The form surface which has high antimicrobial activity could be possibly synthesized with produced silver nanoparticles $[26,27]$.

\section{Conclusion}

The sizes of Ag NPs synthesized by catalyzed peroxidase enzyme obtained from Euphorbia (Euphorbia amygdaloides) plants were in the range from 7 to $20 \mathrm{~nm}$ and in the spherical form. Ag NPs were characterized using UV-vis spectroscopy, SEM, and XRD. The synthesis of Ag NPs was confirmed with performed analysis and characterization of Ag NPs was carried out in terms of size, quantity, direction, and morphology. In addition, the Ag NPs showed excellent antibacterial activity. Thus, synthesized Ag NPs are believed to have potential for use in the creation of new antibacterial floor and surface and the preparation of antimicrobial packaging materials, adhesive plasters, and dressings. 


\section{Conflict of Interests}

The authors have declared that no conflict of interests exists.

\section{Acknowledgments}

This research was performed under Project no. 2014/173 and supported by the Research Development Centre of Ataturk University. The authors acknowledge the support of Ataturk University, Turkey, for this work. The SEM, EDX, and FTIR study of this research was carried out in the Atatürk University Faculty of Science and XRD study of this research was carried out in Atatürk University Faculty of Engineering. So, the authors thank Professor Doctor Umit Demir and Professor Doctor Yasar Totik, respectively.

\section{References}

[1] J. Gupta, "Nanotechnology applications in medicine and dentistry," Journal of Investigative and Clinical Dentistry, vol. 2, no. 2, pp. 81-88, 2011.

[2] H. Xie, M. M. Mason, and J. P. Wise Sr., "Genotoxicity of metal nanoparticles," Reviews on Environmental Health, vol. 26, no. 4, pp. 251-268, 2011.

[3] F. Martinez-Gutierrez, P. L. Olive, A. Banuelos et al., "Synthesis, characterization, and evaluation of antimicrobial and cytotoxic effect of silver and titanium nanoparticles," Nanomedicine: Nanotechnology, Biology, and Medicine, vol. 6, no. 5, pp. 681-688, 2010.

[4] V. K. Sharma, R. A. Yngard, and Y. Lin, "Silver nanoparticles: green synthesis and their antimicrobial activities," Advances in Colloid and Interface Science, vol. 145, no. 1-2, pp. 83-96, 2009.

[5] M. N. Nadagouda, T. F. Speth, and R. S. Varma, "Microwaveassisted green synthesis of silver nanostructures," Accounts of Chemical Research, vol. 44, no. 7, pp. 469-478, 2011.

[6] O. Y. Golubevaa, O. V. Shamova, D. S. Orlov, T. Y. Pazina, A. S. Boldina, and V. N. Kokryakov, "Study of antimicrobial and hemolytic activities of silver nanoparticles prepared by chemical reduction," Glass Physics and Chemistry, vol. 36, no. 5, pp. 628-634, 2010.

[7] M. Harada, C. Kawasaki, K. Saijo, M. Demizu, and Y. Kimura, "Photochemical synthesis of silver particles using water-inionic liquid microemulsions in high-pressure $\mathrm{CO}_{2}$," Journal of Colloid and Interface Science, vol. 343, no. 2, pp. 537-545, 2010.

[8] E. C. Njagi, H. Huang, L. Stafford et al., "Biosynthesis of iron and silver nanoparticles at room temperature using aqueous sorghum bran extracts," Langmuir, vol. 27, no. 1, pp. 264-271, 2011.

[9] M. F. Zayed, W. H. Eisa, and A. A. Shabaka, "Malva parviflora extract assisted green synthesis of silver nanoparticles," Spectrochimica Acta Part A: Molecular and Biomolecular Spectroscopy, vol. 98, pp. 423-428, 2012.

[10] F. Namvar, J. Baharara, T. Ramezani et al., "Green synthesis of silver nanoparticles using Achillea biebersteinii flower extract and its anti-angiogenic properties in the rat aortic ring model," Molecules, vol. 19, no. 4, pp. 4624-4634, 2014.

[11] R. Sahana, S. C. G. Kiruba Daniel, S. G. Sankar, G. Archunan, S. J. Vennison, and M. Sivakumar, "Formulation of bactericidal cold cream against clinical pathogens using Cassia auriculata flower extract-synthesized Ag nanoparticles," Green Chemistry Letters and Reviews, vol. 7, no. 1, pp. 64-72, 2014.
[12] J. Manjanna, S. Yallappa, S. K. Peethambar et al., "Green synthesis of silver nanoparticles using Acacia farnesiana (Sweet acacia) seed extract under microwave irradiation and their biological assessment," Journal of Cluster Science, vol. 24, pp. 1081-1092, 2013.

[13] S. Ashokkumar, S. Ravi, and S. Velmurugan, "Green synthesis of silver nanoparticles from Gloriosa superba L. leaf extract and their catalytic activity," Spectrochimica Acta Part A: Molecular and Biomolecular Spectroscopy, vol. 115, pp. 388-392, 2013.

[14] D. A. Kumar, V. Palanichamy, and S. M. Roopan, "Green synthesis of silver nanoparticles using Alternanthera dentata leaf extract at room temperature and their antimicrobial activity," Spectrochimica Acta Part A: Molecular and Biomolecular Spectroscopy, vol. 127, pp. 168-171, 2014.

[15] R. Mariselvam, A. J. A. Ranjitsingh, A. Usha Raja Nanthini, K. Kalirajan, C. Padmalatha, and P. Mosae Selvakumar, "Green synthesis of silver nanoparticles from the extract of the inflorescence of Cocos nucifera (Family: Arecaceae) for enhanced antibacterial activity," Spectrochimica Acta-Part A: Molecular and Biomolecular Spectroscopy, vol. 129, pp. 537-541, 2014.

[16] S. Akhtar, A. A. Khan, and Q. Husain, "Partially purified bitter gourd (Momordica charantia) peroxidase catalyzed decolorization of textile and other industrially important dyes," Bioresource Technology, vol. 96, no. 16, pp. 1804-1811, 2005.

[17] A. A. Güngör, Y. Demir, and N. Demir, "Purification of peroxidase from latex of Euphorbia (Euphorbia amygdaloides) and investigation of kinetic properties," Asian Journal of Chemistry, vol. 20, no. 1, pp. 477-482, 2008.

[18] K. Vahabi and S. K. Dorcheh, "Biosynthesis of silver nanoparticles by Trichoderma and its medical applications," in Biotechnology and Biology of Trichoderma, V. K. Gupta, M. Schmoll, A. Herrera-Estrella, R. S. Upadhyay, I. Druzhinina, and M. G. Tuohy, Eds., chapter 29, pp. 393-404, Elsevier, London, UK, 2014.

[19] M. R. Bindhu and M. Umadevi, "Synthesis of monodispersed silver nanoparticles using Hibiscus cannabinus leaf extract and its antimicrobial activity," Spectrochimica Acta Part A: Molecular and Biomolecular Spectroscopy, vol. 101, pp. 184-190, 2013.

[20] E. Filippo, A. Serra, A. Buccolieri, and D. Manno, "Green synthesis of silver nanoparticles with sucrose and maltose: morphological and structural characterization," Journal of NonCrystalline Solids, vol. 356, no. 6-8, pp. 344-350, 2010.

[21] M. M. H. Khalil, E. H. Ismail, K. Z. El-Baghdady, and D. Mohamed, "Green synthesis of silver nanoparticles using olive leaf extract and its antibacterial activity," Arabian Journal of Chemistry, vol. 7, no. 6, pp. 1131-1139, 2014.

[22] R. Meenatchiammal and G. V. Bai, Journal of Pharmaceutical, Chemical and Biological Sciences, vol. 4, pp. 101-111, 2014.

[23] S. P. Chandran, M. Chaudhary, R. Pasricha, A. Ahmad, and M. Sastry, "Synthesis of gold nanotriangles and silver nanoparticles using Aloe vera plant extract," Biotechnology Progress, vol. 22, no. 2, pp. 577-583, 2006.

[24] S. S. Shankar, A. Rai, A. Ahmad, and M. Sastry, "Rapid synthesis of $\mathrm{Au}, \mathrm{Ag}$, and bimetallic $\mathrm{Au}$ core-Ag shell nanoparticles using Neem (Azadirachta indica) leaf broth," Journal of Colloid and Interface Science, vol. 275, no. 2, pp. 496-502, 2004.

[25] S. Ashokkumar, S. Ravi, V. Kathiravan, and S. Velmurugan, "Synthesis of silver nanoparticles using A. indicum leaf extract and their antibacterial activity," Spectrochimica Acta Part A: Molecular and Biomolecular Spectroscopy, vol. 134, pp. 34-39, 2015. 
[26] C. Baker, A. Pradhan, L. Pakstis, D. J. Pochan, and S. I. Shah, "Synthesis and antibacterial properties of silver nanoparticles," Journal of Nanoscience and Nanotechnology, vol. 5, no. 2, pp. 244-249, 2005.

[27] J. R. Morones, J. L. Elechiguerra, A. Camacho et al., "The bactericidal effect of silver nanoparticles," Nanotechnology, vol. 16, no. 10, pp. 2346-2353, 2005. 

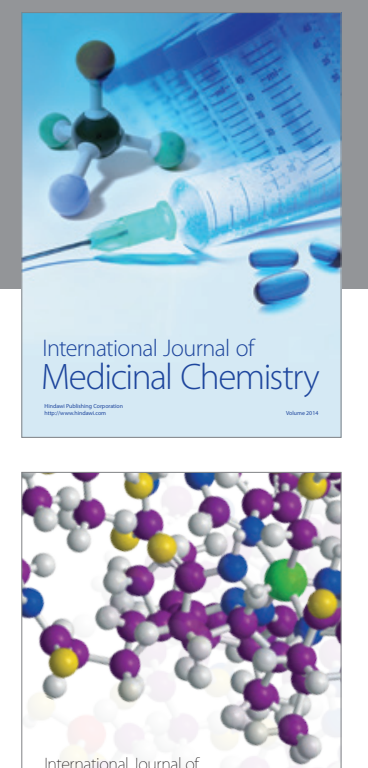

\section{Carbohydrate} Chemistry

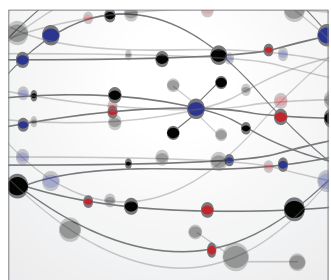

The Scientific World Journal
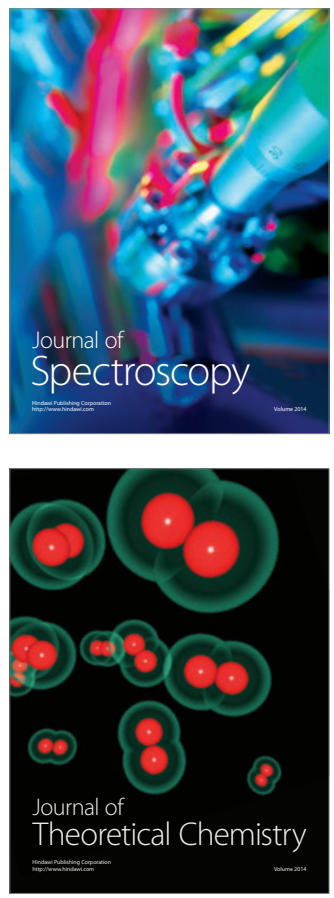
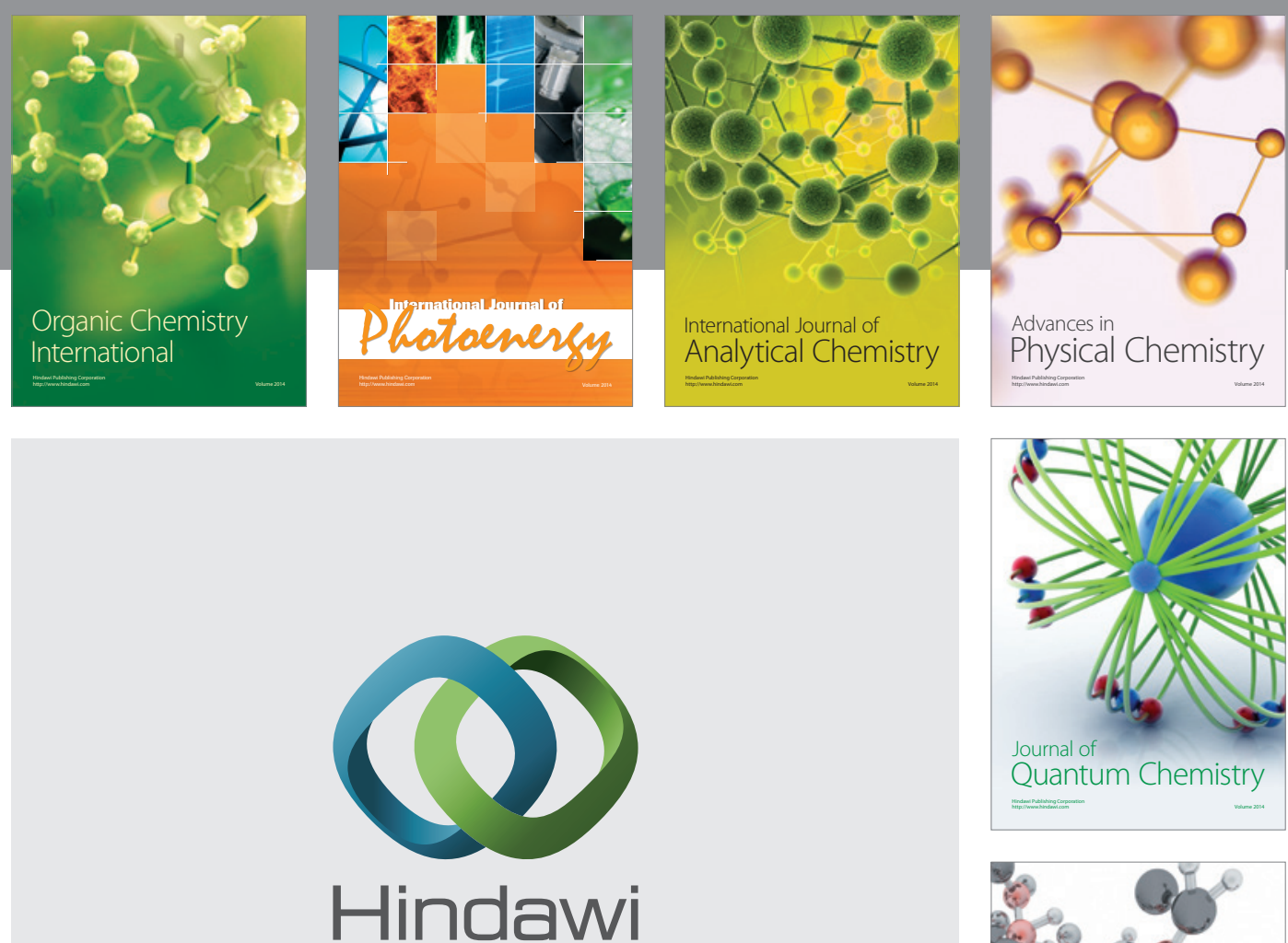

Submit your manuscripts at

http://www.hindawi.com

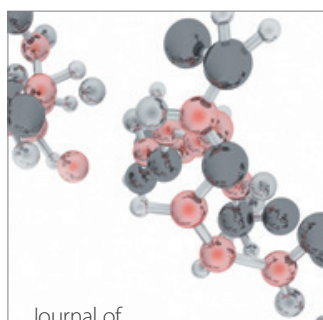

Analytical Methods

in Chemistry

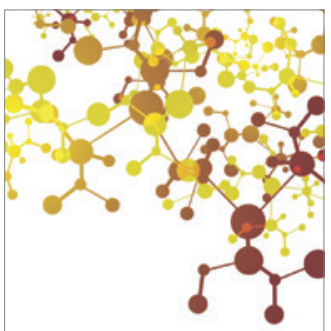

Journal of

Applied Chemistry

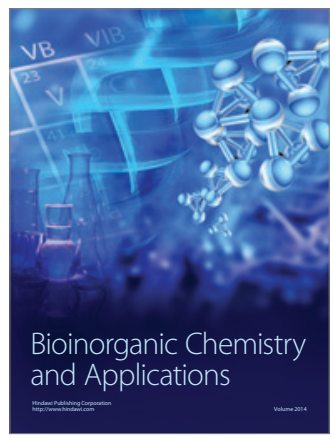

Inorganic Chemistry
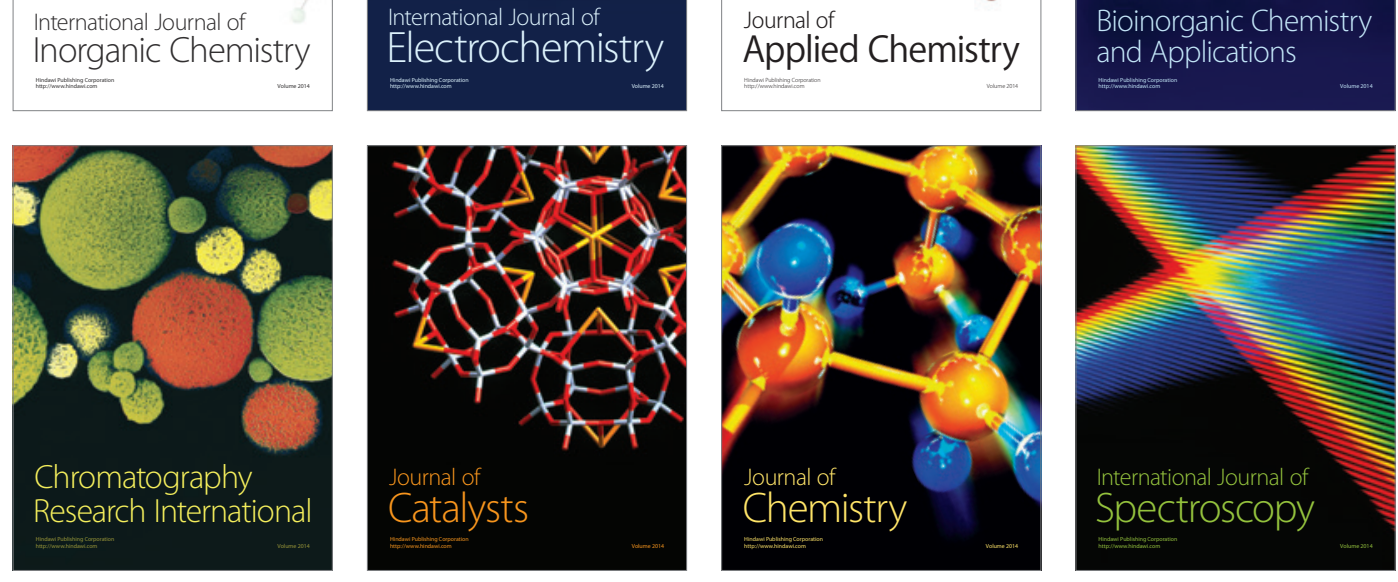